\title{
THE RELATIONSHIP AMONG MANAGERIAL CAPABILITY, ORGANIZATIONAL CITIZENSHIP BEHAVIOR, AND EMPLOYEE PERFORMANCE: MEDIATION EFFECTS OF ORGANIZATIONAL CULTURE
}

\author{
Suharto $^{1 *}$, Jawoto Nusantoro ${ }^{1}$ \\ ${ }^{1}$ Faculty of Economics, Muhammadiyah University of Metro, Lampung, Indonesia \\ *Corresponding Author: hartoumm@gmail.com
}

\begin{abstract}
This study aims to determine the direct effects of managerial skills, organizational citizenship behavior and organizational culture on employee performance. The method used bothered survey method as well as primary data. The fluctuating productivity of MSME is largely due to the relatively high various performance of the employee, and it can disrupt the stability of small businesses as the starting point of this research. The sampling namely with used bothered forcible entry sampling. Chaired by the manifest variables used Likert scale installation design to 160 talk shows us the respondents at MSME in Lampung Province. Testing requirements analysis included lilliefors test normality, homogeneity test, linearity test and regression yew. The data bothered analyzed using structural equation model, namely structural equation modeling. The research results find that managerial ability provides direct effects on organizational culture, organizational citizenship behavior provides direct effects on organizational culture, managerial ability does not provide direct effects on employee performance, organizational citizenship behavior provides direct effects on employee performance and organizational culture provides direct effects on employee performance.
\end{abstract}

Keywords: Managerial Capability, Organizational Citizenship Behavior, Organizational Culture, Employee Performance.

\section{INTRODUCTION}

One of the indicators of the success of a company is the performance of employees who work effectively and efficiently would produce good performance (Singh, et al. 2004). To create the performance of the employees there are a few things that can be considered, among other managerial capabilities, organizational citizenship behavior, and culture of the organization, (Bagire, 2013; Nikpour, 2017). A manager must have the ability to manage the existing resources and every manager has a different leadership method to improve the performance of the employees in an organization (Wakabayashi, et al. 1998). Further by Rivai, et al. (2009); Satulondok (2015), that widely leadership includes the process of influence in determining the purpose of the organization, motivate the behavior of followers to achieve, affect the interpretation of the events of his followers, organising and activities to reach the target, keep the relationship of cooperation and group work, gains support and cooperation from people outside of the group or organization. Prezyna, et al., (2017), said that the manager who has the ability to lead the course can affect employees in carrying out their tasks so that the role of the managers of the companies have an important influence for the performance of the employees of siting a company.

To be able to improve the performance of the employees in addition to managerial capabilities, namely organizational citizenship behavior (OCB). OCB is the behavior of the actions of the employees in carrying out their duties but added with self-awareness in performing activities outside the main tasks (Bukhari, et al. 2009). For example in the company employee help colleagues who have difficulty in a situation that is faced by both of the main tasks of the organization and personal problems of others. Chen (1997); Darmawati, et al. (2013) holds that OCB is a behavior that expands and exceeds the behavior of what has been required by the organization that is contained in a description of the workers.

Other factors that can affect the performance of the employees is the culture of the organization (Moullin, 2017). The term culture organization refers to the culture that occurs in a company or institution because generally the company or institution is in the form of organization. the culture of the organization tends to be related to the values and norms that exist in the organization work. If the organization has developed a positive work culture, then it will benefit the organization activities (Marie, et al., 1994). The benefits can be seen from the results of the work of the members of the organization that meet the specified standards of employment organization. This is in line with that put forward by 
Robbins, 2011; Bagire, 2013; Astrining, 2016, relate that in strong work culture contained the characteristics that the culture of the organization is oriented to the performance of its employees formal (formal job description).

Managerial ability is a set of skills in carrying out the tasks such as planning, directing others and job responsibilities in achieving the purpose of the company (John, 1994; Wakabayashi, et al. 2001). The culture of the organization is a pattern of basic assumptions that studied by a working group from the attitude of the values and norms of behavior that is divided among the members of the organization, Xiaoming, et al., 2012. Thus the managerial capability also must be able to manage the rules in the culture of the organization that aims to achieve the goal of the organization (Chen, et al., 1997; Wakabayashi, et al. 1998), so it can be predicted that managerial capabilities can affect the culture of the organization.

Organizational citizenship behavior is the level of benefits as a way to improve the performance of the employees in the company which taught the initiative and positive action work outside the main tasks such as helping colleagues in the task of the company (Ahmed, et al. 2014). While the culture of the organization is a pattern of basic assumptions that studied by a working group from the attitude of the values and norms of behavior that is divided among the members of the organization (Owoyemi, et al. 2014). At the time of the employees do not perform the redundant action by breaking the norms of culture in the company so that action there is no negative value for the culture and the company so that it can be suspected that the organizational citizenship behavior affects the culture of the organization.

In a company, manager capability is very important to influence the employees in it namely manage and plan the activities of the company (Gronroos, C., 1990; Dehghan, A. 2006). A manager who does not have the ability to influence employees in improving the performance of course coursework emulates monotonous or there is no improvement in a better performance (Moghrabi, et al. 2014). The performance is the result of the good work from the activities of the work of employees and timeliness achieved by an employee in carrying out their tasks in accordance with the responsibility of the given (Onchoke, et al. 2015). Thus managerial capabilities that manage and plan activities at done employees can affect the performance of the employees in accordance with the research (We can make a difference! 2012; Bigelow, 1994), which concluded that managerial ability the positive and significant impact on the performance of the company employee.

Organization citizenship behavior is a set of the benefits of methods used by someone to improve performance in the company. The initiative in learning and positive action work outside the main task as well as help colleagues in the task that already exists in the organization of therapeutic regime governance. (Pavalache, 2014; P. Robbins, 2010). The performance is the result of the good work from the activities of the work of the employees with the accuracy of the time that is used by one of the employees in carrying out their tasks in accordance with the given responsibility. For employees who do work actions outside the tasks can be evaluated by the managers as employees who are active and achievement. From the explanation is suspected of that organization citizenship behavior effect on performance. As has been examined by Pavalache (2014), in the conclusion that says that there is a positive relationship between organizational commitment and organizational citizenship behavior (OCB) on the performance of the employees.

The culture of the organization include a pattern of basic assumptions that learned by working groups and derived from the attitude of the values and norms of behavior that is divided by each of the members of the organization (Leidner, et al., 2013; Owoyemi, et al., 2014; Suharto, 2017). On the other hand, performance is a match between the time and the results of the work of a quality and done by the employees and achieved by a person in carrying out the obligations of standard operating procedures that have been created by the organization. The values and norms that applied the employees in the work allegedly influential on the results of the work or performance of employees in accordance with the research (Shahzad, 2012; Mohanty, 2012, that cultural variable overall organization has a relationship with the employees' performance variable. This is supported by the results of the test of the statistics showed that the relationship between the two variables is positive and significant.

Based on the background and conceptual framework, then conducted research which aims to test the hypothesis managerial capabilities against the culture of the organization, organizational citizenship behavior toward the culture of the organization, managerial capabilities to the performance of the employees, organizational citizenship behavior toward the performance of the employees, and culture of the organization to the performance of employees.

\section{RESEARCH METHOD}

The Approach of research done include quantitative approach with survey methods. This research constellation decides managerial capabilities as an exogenous variable, organizational citizenship behavior exogenous variable, culture organization as the endogenous variable and the performance of the employees of MSMEs as an endogenous variable. The target population is all of the employees of 73 MSMEs in East Lampung, Central Lampung, and Metro City as much as 160 respondents. 
The instrument used in this study is the multiple choice with 5 elect using Likert scale model for managerial ability variable, organizational citizenship behavior, The culture of the organization and the performance of employees. The procedure for the preparation of the instrument covers the development dimension and the indicator in the making of the instrument, testing the validity and reliability improvement of instruments, finalization, and data collection using the instrument.

Testing the reliability of using the consistency of respondents, (Dachlan, 2014), including managerial capabilities, organizational citizenship behavior, The culture of the organization and the performance of employees. Formula testing the validity of using chromatic "product Moment" (Ghozali, 2011), and testing the reliability of using "Cronbach coefficient's Alpha" (Hair, et al. 2010). Data analysis techniques using structural equation modeling, while using test normality analysis requirements, homogeneity, linearity, and regression significance.

\section{RESEARCH RESULTS}

Before done data analysis, required test analysis requirements :

\subsection{Analysis of the Data Normalitas Requirements Test}

The results of this test are used to determine the relationship between the variables with the requirements that each of the variables must have the spread of the normal.

Table 1. The Summary of the Test Requirements of the Normality

\begin{tabular}{|c|c|c|c|c|c|}
\hline No. & $\begin{array}{c}\text { Estimated Regression } \\
\text { Error }\end{array}$ & $\mathrm{L}_{\text {value }}$ & $\mathrm{L}_{\text {table }}$ & Decission & Conclusion \\
\hline 1. & Y1 on X1 & 0.069 & 0,070 & $\mathrm{H}_{0}$ Acceptable & Normal \\
\hline 2. & Y1 on X2 & 0.013 & 0,070 & $\mathrm{H}_{0}$ Acceptable & Normal \\
\hline 3. & Y2 on X1 & 0.109 & 0,070 & $\mathrm{H}_{0}$ Unacceptable & Un normal \\
\hline 4. & Y2 on X2 & 0.052 & 0,070 & $\mathrm{H}_{0}$ Acceptable & Normal \\
\hline 5. & Y2 on Y1 & 0.049 & 0.070 & $\mathrm{H}_{0}$ Acceptable & Normal \\
\hline
\end{tabular}

\subsection{Analysis Requirements Homogenity Test}

The results of this test are used to determine the relationship between the variables with the requirements that each of the variables must have a homogeneous relationship.

Table 2. The Summary of the Test Requirements of the Homogenity

\begin{tabular}{|c|c|c|c|c|}
\hline No. & Variable & $\mathrm{X}_{\text {value }}^{2}$ & $\mathrm{X}_{\text {table }}^{2}$ & Conclusion \\
\hline 1. & Y1 on X1 & 34,394 & 136,591 & Homogeneous \\
\hline 2. & Y1 on X2 & 80,368 & 150,989 & Homogeneous \\
\hline 3. & Y2 on X1 & 11,072 & 136,591 & Homogeneous \\
\hline 4. & Y2 on X2 & 61,791 & 150,989 & Homogeneous \\
\hline 5. & Y2 on Y1 & 32,371 & 146,567 & Homogeneous \\
\hline
\end{tabular}

\subsection{Test Analysis Linieritas requirements and significant Regression}

The results of this test are used to determine the relationship between the variables with the requirements that each of the variables must have the relationship that additional liners and regression significance.

Table 3. The Summary of Test of Requirements, Significance Linearity Regression

\begin{tabular}{|c|c|c|c|c|c|c|}
\hline \multirow{2}{*}{ Variable } & \multicolumn{2}{|c|}{ Sig. Regression } & \multirow{2}{*}{ Sig regression } & \multicolumn{2}{|c|}{ Lin. Regression } & \multirow{2}{*}{$\begin{array}{l}\text { Linearity } \\
\text { Regression }\end{array}$} \\
\hline & $F_{\text {value }}$ & $F_{\text {table }}$ & & $F_{\text {value }}$ & $\mathrm{F}_{\text {table }}$ & \\
\hline $\mathrm{Y}_{1}$ on $\mathrm{X}_{1}$ & 5.59 & 2,12 & Significant & 0.73 & 2,12 & Linearity \\
\hline $\mathrm{Y}_{1}$ on $\mathrm{X}_{2}$ & 76,26 & 2,12 & Significant & 0.06 & 2,12 & Linearity \\
\hline $\mathrm{Y}_{2}$ on $\mathrm{X}_{1}$ & 2.34 & 2,12 & Significant & 0.55 & 2,12 & Linearity \\
\hline $\mathrm{Y}_{2}$ on $\mathrm{X}_{2}$ & 169,6 & 2,12 & Significant & 0.05 & 2,12 & Linearity \\
\hline $\mathrm{Y}_{2}$ on $\mathrm{Y}_{1}$ & 183,8 & 2,12 & Significant & 0.06 & 2,12 & Linearity \\
\hline
\end{tabular}

\subsection{The results of the calculation of the path Coefficient, $t_{v a l u e}$}

After the review of the requirements analysis is done, next is doing the calculation and testing of each path coefficient as presented in the following table:

Table 4. The Summary of Results of the Path Coefficients

\begin{tabular}{|c|c|c|c|c|c|}
\hline \multirow{2}{*}{ No. } & Variable & \multicolumn{2}{|c|}{ The Path Coefficients $(\rho)$} & Decission & Conclusion \\
\cline { 3 - 4 } & & SLF $^{*}$ & $\mathrm{~T}_{\text {value }}$ & & \\
\hline 1. & $\mathrm{Y}_{1}$ on $\mathrm{X}_{1}$ & 0.13 & 2.02 & $\mathrm{H}_{0}$ Unacceptable & Significant \\
\hline
\end{tabular}




\begin{tabular}{|c|c|c|c|c|c|}
\hline 2. & $\mathrm{Y}_{1}$ on $\mathrm{X}_{2}$ & 0.72 & 8.09 & $\mathrm{H}_{0}$ Unacceptable & Significant \\
\hline 3. & $\mathrm{Y}_{2}$ on $\mathrm{X}_{1}$ & $-0,04$ & $-0,71$ & $\mathrm{H}_{0}$ accepted & Non Significant \\
\hline 4. & $\mathrm{Y}_{2}$ on $\mathrm{X}_{2}$ & 0.56 & 6.28 & $\mathrm{H}_{0}$ Unacceptable & Significant \\
\hline 5. & $\mathrm{Y}_{2}$ on $\mathrm{Y}_{1}$ & 0.41 & 4,58 & $\mathrm{H}_{0}$ Unacceptable & Significant \\
\hline
\end{tabular}

*Standardized Loading Factor

\subsection{The Path Coefficient Sub-Struktur 1}

The path coefficient analysis Model sub-structure 1 is stated in the form of common $Y_{1}=\beta_{31} X_{1}+\beta_{32} X_{2}+\varepsilon_{1}$. This testing will give decision-making hypothesis test 1 , and 2 .

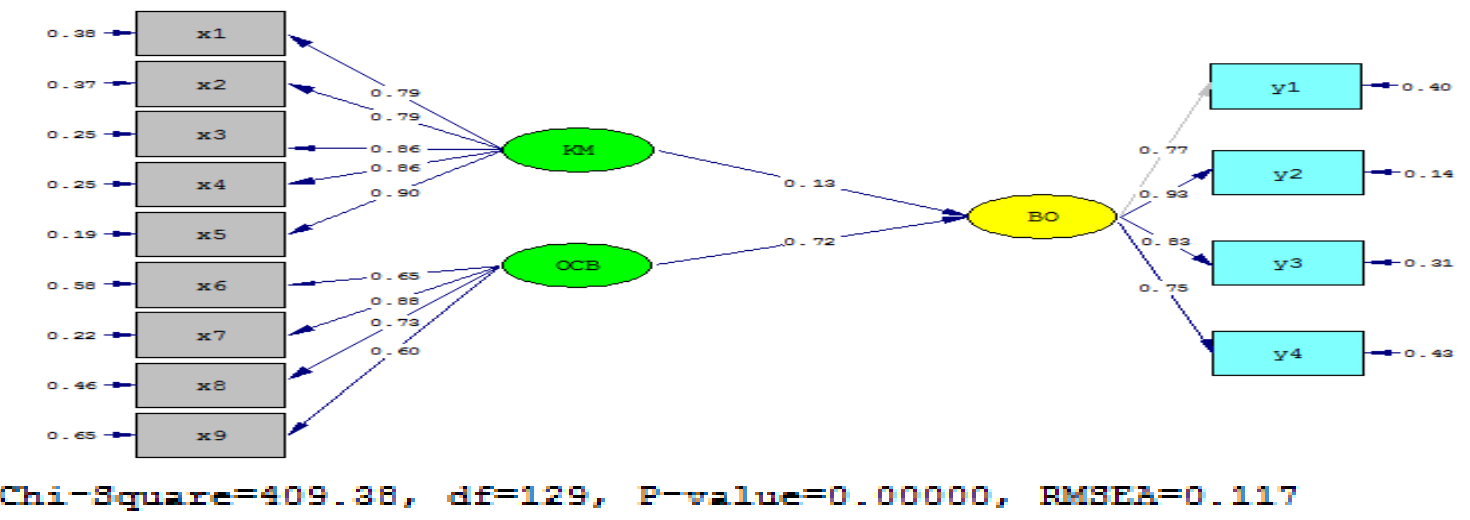

Picture 1. Coefficient Sub-Struktur 1

Based on the testing of the sub-structure of 1 obtained coefficient band $\left(\beta_{31}\right)$ of 0.13 and value of $t_{\text {value }}=2.03>$ $\mathrm{t}_{\text {table }(0.05: 160)}=1.97$ then $\mathrm{H}_{0}$ rejected and path coefficient $\beta_{31}$ is significant, means managerial capabilities directly affects positively to the culture of the organization. The path coefficient $\left(\beta_{32}\right)$ of 0.72 and the value of $t_{\text {value }}=$ $8.09>\mathrm{t}_{\text {table }(0.05: 160)}=1.97$ then $\mathrm{H}_{0}$ rejected and drag coefficient band $\left(\beta_{32}\right)$ is significant, means organizational citizenship behavior directly affects positively to the culture of the organization.

\subsection{The Path Coefficient Sub-Struktur 2}

The path coefficient analysis Model sub-structure 2 is stated in the form of common $Y_{2}=\beta_{41} X_{1}+\beta_{42} X_{2}+\beta_{43} Y_{2}+\varepsilon_{2}$. This testing will give decision-making hypothesis test 3,4 , and 5 .

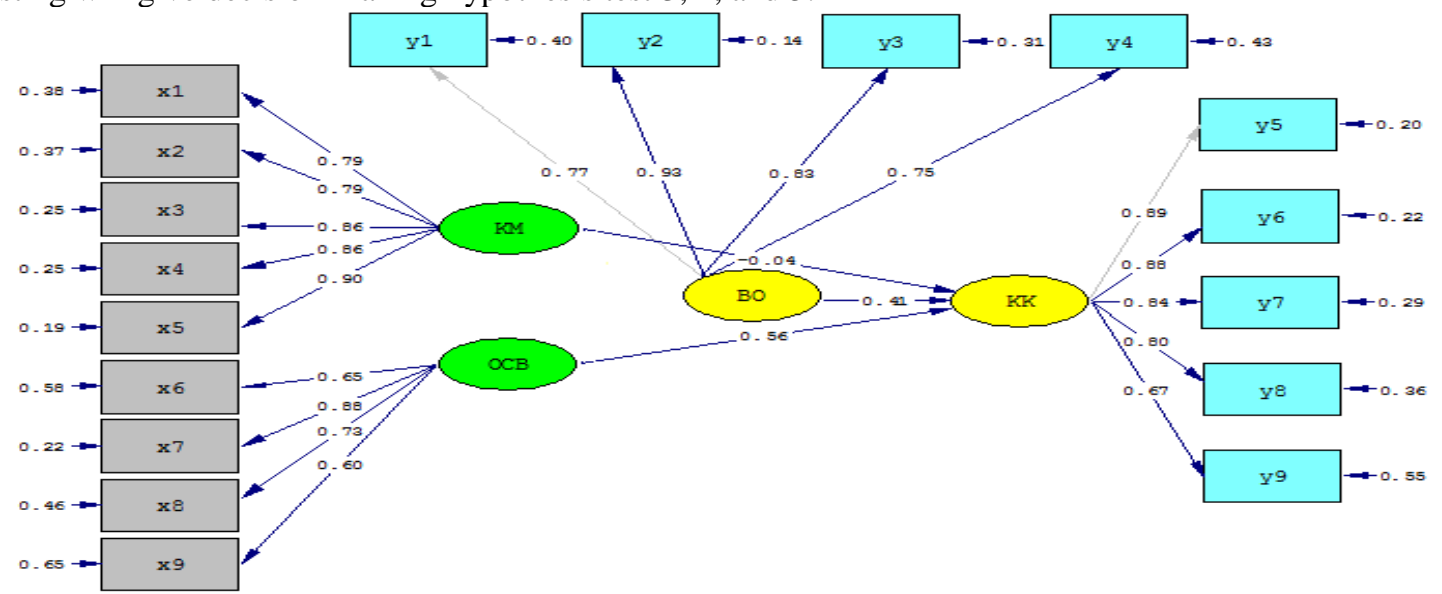

Picture 2. The Path coefficient Sub-Struktur 2

Based on the testing of the sub-structure of 2 obtained path coefficient $\left(\beta_{41}\right)$ of $-0,04$ and value of $t_{\text {value }}=-$ $0,71,54<\mathrm{t}_{\text {table }(0.05: 160)}=1.97$ then $\mathrm{H}_{0}$ received so that the path coefficient $\left(\beta_{41}\right)$ is not significant. This means that the managerial ability does not affect directly to the performance of employees. Chromatic band $\left(\beta_{42}\right)$ of 0.56 and value of $t_{\text {value }}=6.28>\mathrm{t}_{\text {table }(0.05: 160)}=1.97$ then $\mathrm{H}_{0}$ rejected so path coefficient $\left(\beta_{42}\right)$ is significant. This means that the organizational citizenship behavior directly affects positively to the performance of employees. Path coefficient $\left(\beta_{43}\right)$ of 0.56 and value of $t_{\text {value }}=6.28>t_{\text {table }(0.05: 150)}=1.97$ then $\mathrm{H}_{0}$ rejected so path coefficient $\left(\beta_{43}\right)$ is significant. This means that the culture of the organization directly affects positively to the performance. Based on the calculation of the line and the coefficient $t$-value for the purpose of testing the hypothesis that specified, shows that the four path coefficient $<0.05$ and $t$-value $>1.97$, so $\mathrm{H}_{0}$ rejected and four path coefficients is significant. 
The overall line diagram standardized solution on each of the variables are described as follows:

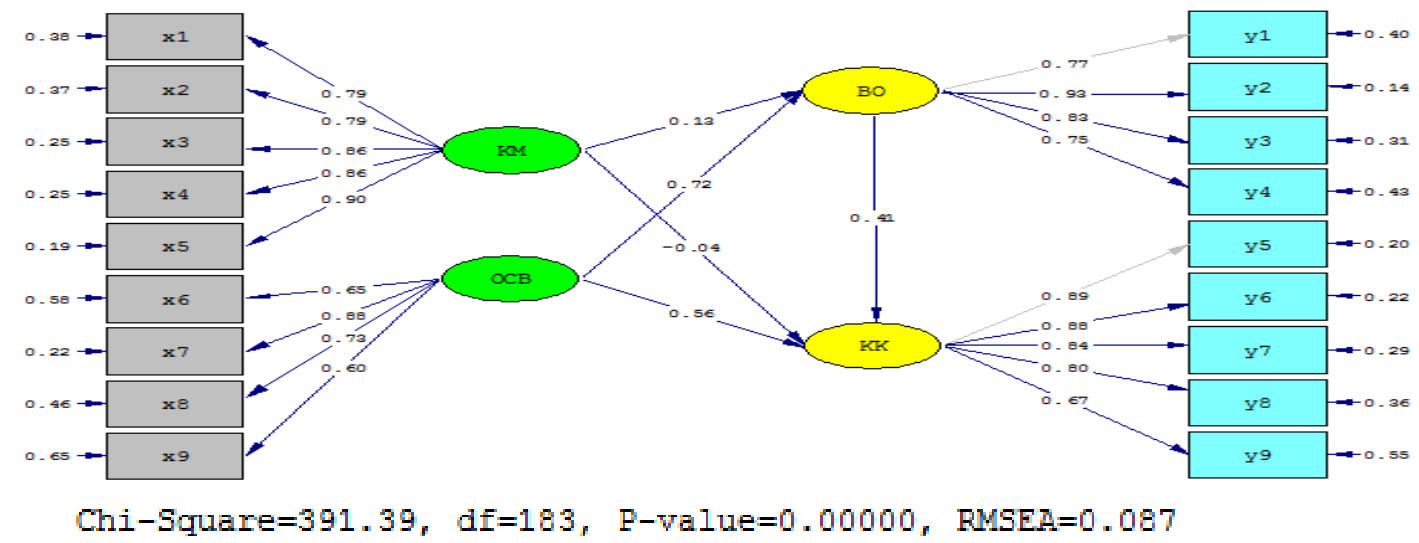

Figure 3: Line Diagram Standardized Solution

Based on picture 3 ( the diagram standardized path solution), in addition to the direct effect (direct), there is also the influence of the total and not directly (indirect) between exogenous variables (X) with endogenous variables (Y). Based on the lisrel output about standardized total effect shows that: (1) The total value of the influence of (total effect) managerial ability variables $\left(\mathrm{X}_{1}\right)$, and organizational citizenship behavior $\left(\mathrm{X}_{2}\right)$ against the culture of the organization $\left(\mathrm{Y}_{1}\right)$ also the same with the value of the influence of the direct effect of each variables, because it is not mediated by the intervening variable, (2) The total value of the influence of (total effect) managerial ability variables $\left(\mathrm{X}_{1}\right)$, organizational citizenship behavior $\left(\mathrm{X}_{2}\right)$, and culture of the organization $\left(\mathrm{Y}_{1}\right)$ against the performance $\left(\mathrm{Y}_{2}\right)$ together with the value of the direct effect (direct effect of each variables, because it is not mediated by other variables (intervening variable), (3) the influence does not directly (indirect effect) managerial ability variables $\left(\mathrm{X}_{1}\right)$ against the performance $\left(\mathrm{Y}_{2}\right)$ of $-0,10 \times 0.25=-0,025$, due to other variables (intervening variable) namely culture organization $\left(\mathrm{Y}_{1}\right)$ of 0.25 , while total influence of $-0,09+(-0,025)=-0,115$ and (4) the influence does not directly (indirect effect variable organizational citizenship behavior $\left(\mathrm{X}_{2}\right)$ against the performance $\left(\mathrm{Y}_{2}\right)$ of $0.59 \times 0.25=0,148$ due to intervening variables namely culture organization $\left(\mathrm{Y}_{1}\right)$ of 0.25 , while total influence is $0.67+0,148=0,818$.

Description of the total influence of exogenous variables $(\mathrm{X})$ against the endogenous variable $(\mathrm{Y})$ above shows that the variable $X_{1}$ and $X_{2}$ directly affect positively for $Y_{2}$ due to intervening (mediation) variables $Y_{1}$ has the value of the influence that is greater than with the variables which are not mediated through other variables. In other words, managerial capabilities, organizational citizenship behavior and culture of the organization with the same affect the performance of the employees have a value greater influence compared with only one variable (X) that affect the performance of the employees. This also happened in the variable managerial capabilities that the capability of the managerial and organizational citizenship behavior together with affect the culture of the organization has value greater influence compared with only one variable $(\mathrm{X})$ that affect the culture of the organization.

\section{DISCUSSION}

\subsection{There Is The Influence Of Managerial Capabilities To The Culture Of The Organization}

The results of the research find that managerial ability directly affects positively to the culture of the organization. It shows that if the managerial capabilities are able to show managerial functions such as planning, organization, leadership, and control run with maximum and provide the motivation to members of the organization that can be done. The results of this research in accordance with the theory presented by Siagian, in we can make a difference!, (2013); Bagire, 2013, that managerial ability is the ability to manage the business such as planning, organizing, giving motivation supervision and assessment.

4.2 There Is The Influence Of Organizational Citizenship Behavior Toward The Culture Of The Organization The results of the research find that organizational citizenship behavior directly affects positively to the culture of the organization. This indicates if such as help another individual in the team to perform the tasks and responsibilities, increase the level of conductivity, honor the spirit and the contents of the rule then will cause employees to work together with the organization. The results of this research in accordance with the research examined Wirawan, 2013; Mohanty, 2012. OCB is a voluntary behavior work venues carried out by the employees freely that outside the job requirements of the person and the terms of the organization so that there is no reward system in the organization that if implemented employee will improve the functioning of the organization

\subsection{There Is The Influence Of Managerial Capabilities To The Performance Of Employees}

The results of the research finds that managerial capabilities are not directly affected positively by the performance of employees and it shows that managerial capabilities that consists of the indicators of managerial functions such as planning, organization, leadership and control run with maximum does not affect the results of the work that 
everything someone in carrying out the tasks to maintain technical services based on the job requirements, the appearance of the work and the potential for a person in an effort to develop themselves to the interests of the organization of the task that the appropriate given responsibility. These findings in accordance with the research Bagire, 2013, that managerial ability affect the performance of the employees.

\subsection{There Is The Influence Of Organizational Citizenship Behavior On The Performance Of The Employees}

The research results suggest that organizational citizenship behavior directly affects positively to the performance of employees. This shows that if the behavior of employees who exceed the role that required outside the tasks performed by the employees who were not given the reply services to maintain and develop positive attitude, honor the spirit and the contents of the regulations as well as to be tolerant toward a loss related to the work that happens sometimes repaired, then the results of the work that everything someone in carrying out the tasks to maintain technical services based on the job requirements, the appearance of the work and the potential for a person in an effort to develop themselves to the interests of the organization of the duty that falls according to the responsibility given the better and in accordance with the research Wirawan, 2013.

\subsection{There Is The Influence Of The Culture Of The Organization To The Performance Of Employees}

The research results suggest that the culture of the organization directly affects positively to the performance of employees. This shows that the culture of the organization can accommodate the level of the diversity of the members of the organization with maximum, so that wakes up the environmental organizations to be conductive tape and work motivation is getting higher so realize maximum employees performance. This research in accordance with the research examined by Aryanti, 2014; Darmawati, et al., 2013. Based on the results of the calculations found that the culture of the organization affects the performance of the employees.

\section{CONCLUSIONS AND RECOMMENDATIONS}

\subsection{Conclusion}

Based on the data collected and testing done, so it can be taken of the conclusions as follows:

1) Managerial capabilities have a positive effect on the culture of the organization because managerial capabilities are able to show managerial functions such as planning, organization, leadership, and control run with maximum and provide the motivation to members of the organization.

2) Organizational citizenship behavior affects the culture of the organization. This indicates if the employees can help another individual in the team to perform the tasks and responsibilities, improve conductivity level organization, honor the spirit and the contents of the rule then will be a desire to work together with the organization.

3) Managerial ability does not affect the performance because employees and the organization working according to the SOP at and managerial function has not been carried out with the maximum.

4) Organizational citizenship behavior affects the performance of the employees that another individual can make a working team, perform the tasks and responsibilities, complete tasks with good managers will assess that employees have a separate value that needs to be given credit for the good work achievement.

5) The culture of the organization affects the performance of the employees. This shows that the culture of the organization can accommodate the level of the diversity of the members of the organization with maximum, so that wakes up the environmental organizations to be conductive tape and work motivation is getting higher so realize maximum employees performance.

\subsection{Recommendations}

Now the suggestions for doing this research are as follows:

1) The attitudes and behavior of the managers will be a reflection for members of the organization and therefore it is expected that the party managers for can give a good example to the members of the organization.

2) To minimize the gap that will occur in the organization, should employees who help another individual and team to remain stuck on the rules that have been agreed with them.

3) Managers need to improve their ability to interact with employees. Because with the existence of the interaction will arise a solution that will help in influencing subordinate.

4) Employees who can improve the attitude of tolerance and cooperation against colleagues who created the good working relationship with fellow workers will surely make work feel comfortable and can improve performance.

5) Rules that are made in the organization should be to build the spirit of employees in the work so that the employees can work with bubbly and not feel burdened which in the end can reduce the performance.

\section{REFERENCES}

Ahmed, Mashal \& Saima Shafiq. (2014). Global Journal of Management and Business Research: A Admin istration and Management Volume 14 Issue 3 Version 1.0 Year 2014 Double Blind Peer Reviewed International Research Journal. Online ISSN: 2249-4588 \& Print ISSN: 0975-5853. The Impact of Organizational Culture on Organizational Performance: A Case Study of Telecom Sector. Islamia University of Bahawalpur, Pakistan.

Aryanti, Nel. (2014). Pengaruh Budaya Organisasi Terhadap Kinerja Pegawai. Universitas Muhammadiyah Sumatera: Jurnal Manajemen \& Bisnis Vol 14 No. 02. 
Astrining, Succi. (2016). Pengaruh Budaya Organisasi Terhadap Kinerja Karyawan Melalui Organization Citizenship Behavior Sebagai Variabel Intervening. Jurnal Ilmu Manajemen Volume 4 Nomor 3.

Bagire, Vincent dan Juliana Namada. (2013). Managerial Skills, Financial Capability and Strategic Planning in Organizations. Published Online September 2013. Department of Business Administration, Makerere University Business School, Kampala, Uganda, and Department of Business Administration, School of Business, University of Nairobi, Nairobi, Kenya. American Journal of Industrial and Business Management, 3, 480-487.

Bigelow, John D. (1994). International Skills for Managers: Integrating International and Managerial Skill Leaming. Asia Pasific Journal of Human Resources. Boise State University. Vol. 32, Issue 1, 1994.

Bukhari, Zirgham Ullah dan Umair Ali. (2009). International Journal of Business and Management. Relationship between Organizational Citizenship Behavior \& Counterproductive Work Behavior in the geographical Context of Pakistan. International Journal of Business and Management. Vol. 4, No. 1 January.

Chen, Z. and M. Wakabayashi. (1997). 'Managerial Skills in Chinese State-owned Corporations', Japanese Journal of Administrative Behavior, 11(1): 35-48.

Dachlan, Usman. (2014). Panduan Lengkap Structural Equation Model. Semarang: Lentera Ilmu.

Darmawati, Arum, et al. (2013). Pengaruh Kepuasan Kerja dan Komitmen Organisasi Terhadap Organization Citizinship Behavior. Jurnal Economia, Volume 9, Nomor 1, April 2013.

Dehghan, A. (2006). Relationship between Service Quality and Customer Satisfaction. Thesis, Luella University of Technology.

Ghozali, Imam. (2011). Aplikasi analisis multivanate dengan program SPSS. Semarang: Penerbit UNDIP.

Gronroos, C. (1990). Service Management and Marketing: Managing the Moment of Truth in Service Competition. Massachusetts: Lexington.

Hair, J. F., Black, W. C., Babin, B. J., Anderson, R. E. (2010). Multivariate Data Analysis: A Global Perspective

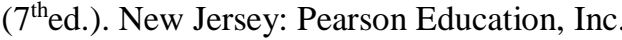

Irawati, Rina dan Yuyuk Liana. (2013). Pengaruh Gaya Kepemimpinan Transformasional dan Kepuasan Kerja terhadap Kinerja Karyawan dengan Komitmen Organisasi Sebagai Variabel Antara. Jurnal Ilmiah ESAI. Vol. 7 No. 3 ISSN: 1978-6034. STIE Malangkucecwara.

Irawati, Rina. (2012). Pengaruh Kemampuan Manajerial dan Motivasi Terhadap Kinerja Pewirausaha Kecil/MIikro Melalui Kepuasan Kerja. Jurnal 2127-6143-1-PB-Pdf.

Leidner, D.E., and T. Kayworth. (2013). "Review: A Review of Culture in Information System Research: Toward a Theory of Information Technology Culture Conflict”. Vol. 30, no. 2, pp. 357-399.

Marie C. Trigg and David Trigg. (1994). Currently published as: Cross Cultural \& Strategic Management. Online from. Disney's European theme park adventure: a clash of cultures, Australia. Cross Cultural Management: An International Journal. Department of Management. Royal Melbourne Institute of Technology, Australia.). ISSN: 1352-7606.

Moghrabi, Kamel M., Abdel-Aziz Ahmad Sharabati, and Mahmoud Khader. (2014). Impact of Managers Skills Profile on His Managerial Behavior A Case Study of Jordan Kuwait Bank. International Review of Management and Business Research. Business Management Department, Business College, Middle East University AmmanJordan. June 2014. Vol. 3 Issue 2.

Mohanty, Jagannath and Bhabani P Rath. (2012). Influence Of Organizational Culture On Organizational Citizenship Behavior: A Three-Sector Study, Institute Of Management Technology, Nagpur. Berhampur University, Berhampur. Global Journal Of Business Research, Volume 6, Number 1.

Moullin, Max. (2017). Improving and evaluating performance with the Public Sector Scorecard. Max Moullin, (Sheffield Business School, Sheffield Hallam University, Sheffield, UK). "Improving and evaluating performance with the Public Sector Scorecard". International Journal of Productivity and Performance Management. ISSN: 1741-0401. Vol. 66 Issue: 4, pp. 442-458.

Nikpour, Amin. (2017). International Journal of Organizational Leadership 6, 65-72. International Journal Of Organizational Leadership. Industrial Management Institute. The impact of organizational culture on organizational performance: The mediating role of employee's organizational commitment. Assistant Professor, Department of Management, Kerman Branch, Islamic Azad University, Kerman, Iran.

Onchoke, George Mogambi, Margret Oloko, Geoffrey Ongondo Obonyo. (2015).The International Journal Of Business \& Management. The International Journal Of Business \& Management. Influence of Managerial Skills on Performance of Departmental Heads in Public Secondary Schools: A Survey of KISII Central SubCounty. JKUAT, Kenya. ISSN 2321 -8916. Vol 3 Issue 2. February, 2015. p. 135.

Owoyemi O. O. and Ekwoaba J.O. (2014). Organisational Culture: A Tool for Management to Control, Motivate and Enhance Employees' Performance. Department of Industrial Relations and Personnel Management, University of Lagos, Nigeria. American Journal of Business and Management. Vol. 3, No. 3, 2014, 168-177 DOI: 10.11634/ 216796061403514. ISSN 2167-9606 Print/ ISSN 2167-9614 Online/ World Scholars.

P. Robbins, Stephen. (2010). Organizational Behaviour. Tenth Edition. Perilaku Organisasi Edisi ke Sepuluh, Alih Bahasa Drs. Benyamin Molan. Jakarta: Salemba Empat.

P. Siagian, Sondang. (1997). Manajemen Sumber Daya Manusia, Jakarta: Bumi Aksara. 
Pavalache, Mariela and Sorin Cocorada. (2014). Interactions of Students' Personality in the Online Learning Environment. Mariela Pavalache-Ilie. Sorin Cocorada. Procedia. Social and Behavioral Sciences. Volume 128, 22 April 2014, Pages 117-122.

Pavalache, Mariela. (2014). Organizational Citizenship Behaviour, Work Satisfaction and Employees' Personality. Procedia - Social and Behavioral Sciences. Volume 127, 22 April 2014, p. 489-493.

Prezyna, Dolores Marie, Mark J Garrison, Carol P Gold, Hilary A Lockte. (2017). Principal Leadership and Reading Specialist Role Understanding in the Era of Test-Based Accountability Policies. International Journal of Education Policy and Leadership. Vol 12, No. 2 (2017). ISSN: 1555-5062.

Rivai, Veithzal dan Deddy Mulyadi. (2009). Kepemimpinan dan Perilaku Organisasi. Jakarta: PT. Rajagrafindo Persada.

Robbins SP, dan Judge. (2011). Perilaku Organisasi. Jakarta: Salemba Empat.

Satulondok, dkk. 2015. Pengaruh Kepemimpinan, Motivasi, Kondisi Kerja dan Disiplin Terhadap Kinerja Pegawai Di Kantor Sekretariat DPRD Kota Sorong. Jurnal EMBA Vol. 3 No. 3 September 2015, Hal. 849-862. ISSN 2303-11.

Shahzad, Fakhar. Rana Adeel Luqman. Ayesha Rashid Khan. Lalarukh Shabbir. (2012) Impact of Organizational Culture on Organizational Performance: An Overview. Interdisciplinary Journal Of Contemporary Research In Business. January Vol. 3, No 9.

Singh, Davinder. JS Khamba. Tarun Nanda. (2004). International Journal of Productivity and Performance Management. Previously published as: Work Study. Online from: 2004. Influence of technological innovation on performance of small manufacturing companies. ISSN: 1741-0401. Emeraldinsight.

Suharto. (2017). Mediation of Emotional Intelligence on Self-efficacy, Organizational Culture, and Responsiveness. https://journal-biotika.com/current-issues/ 2017-04/article_08.pdf

Wakabayashi, M. and Z. Chen. (1998). 'Managerial Skills for Asian Managers: Comparisons Based on Managers in Japanese, Chinese and Filipino Corporations ', Forum of International Development Studies, 12(1): 1-17.

Wakabayashi, Mitsuru, Mari Kondo dan Ziguang Chen. (2001). Cross-cultural Managerial Skill Practices: Filipino and Chinese Managers under Japanese-style Management. Nagoya University, Japan. Volume: 2 issue: 1, page(s): 15-35. February 1.

Wirawan. (2013). Kepemimpinan. Depok: PT. Raja Grafindo Persada.

Xiaoming, Cui and Hu Junchen. (2012). International Journal of Business Administration. Vol. 3, No. 2 ; March 2012. School of Management, Fudan University, Shanghai, China; ISSN 1923-4007, E-ISSN 1923-4015. 